\title{
PENGARUH PROMOSI, FASILITAS DAN LOKASI DALAM MENINGKATKAN KEPUTUSAN BERKUNJUNG PADA PERMANDIAN MILENIUM WATERPARK PALU
}

\author{
Albar Alaydrus ${ }^{1}$, Labandingi Latoki ${ }^{1}$ dan Zulkifli $^{2}$ \\ ${ }^{1}$ Dosen Fakultas Ekonomi Universitas Alkhairaat \\ ${ }^{2}$ Mahasiswa Fakultas Ekonomi Universitas Alkhairaat
}

\begin{abstract}
ABSTRAK
Penelitian ini mengungkapkan Pengaruh Promosi, Fasilitas dan Lokasi Terhadap Keputusan Berkunjung Pada Permandian Millennium Waterpark Palu. Tujuan yang ingin dicapai dalam penelitian ini Untuk mengetahui Pengaruh Promosi, Fasilitas dan Lokasi Terhadap Keputusan Berkunjung Pada Permandian Millennium Waterpark Palu. Metode yang digunakan Penelilti bersifat Deskriptif dengan alat bantu koesioner terhadap 100 responden. Hasil penelitian ini membuktikan bahwa melihat pengaruh variabel promosi, fasilitas dan lokasi terhadap keputusan berkunjung pada permandian millennium waterpark Palu sebesar 66,4\% artinya pengaruh variabel bebas (independen) terhadap variabel terikat (dependen). Sedangkan sisanya 33,6\% adalah pengaruh variabel lain yang tidak diteliti dalam penelitian ini.
\end{abstract}

Kata Kunci: Keputusan Berkunjung, Promosi, Fasilitas dan Lokasi.

\section{LATAR BELAKANG}

Kota Palu merupakan ibu kota Sulewesi Tengah, yang memiliki objek wisata permandian salah satunya ialah permandian Milenium Waterpark Palu, permandian ini berlokasi di tengah - tengah Kota Palu, yaitu jalan Emmy Saelan nomor 17, permandian Milenium Waterpark ini berdiri sejak tahun 2003, yang di dirikan oleh Bapak Wijaya Candra selaku pemilik, wisata ini dalam proses pembangunannya kurang lebih satu stenga tahun.

Fasilitas-fasilitas yang ada pada permandian Milenium Waterpark ialah kolam anak, kolam khusus dewasa,kolam arus, seluncuran paus, dan seluncuran naga (waterboom) yang memiliki ketinggian 7 kaki. Selain itu permandian ini juga memiliki fasilitas penunjang, diantaranya ialah mushollah, musik khusus dihari libur, kamar ganti, kamar kecil, gazebo yang digunakan beristrahat dan bersantai, kursi beserta majah di pinggir kolam, kafe, dan kantin. dan yang tak kala bagusnya lagi, tempat ini dihiasi dengan patung - patung yang unik, air tejun mini, kolam ikan, dan gambar 3 dimensi Benua Atlantik, sehingga pemandangan di lokasi Milenium Waterpark menghasilkan pemandangan yang indah dan unik. Maka tidak heran permandian ini banyak diminati oleh pengunjung.
Menurut (Latoki, 2019) Salah satu upaya yang dilakukan dalam menghadapi persaingan yaitu memberikan kualitas pelayanan yang terbaik kepada konsumen, kualitas pelayanan tersebut terdiri dari kualitas produk, harga, distribusi dan promosi. Hal ini dilakukan semata-mata bertujuan untuk mendapatkan kepuasan yang diinginkan konsumen.

Demi menjaga kepuasan Pengunjung terhadap fasilitas-fasilitas yang disediakan, sekaligus menjaga agar keputusan tamu atau konsumen tidak bepaling ke tempat wisata lain, pihak Milenium Waterpark awal bulan februari 2015 merehap kolam anak menjadi wahana baru, dan pengunjung dapat menggunakan wahana baru tersebut pada Bulan April atau Mei 2015. Selain itu pihak Milenium Waterpark melakukan pembaharuan (mengecat) kembali seluruh lokasi permandian Milenium Waterpark.

Tujuan di buatnya wahana baru dan pengecetan kembali seluruh lokasi Milenium Waterpark, berguna untuk memberi suasana baru sekaligus untuk meningkatkan keputusan masyarakat berkunjung.

Berikut tabel 1 yang menunjukan julah pengunjung pada permandian Milenium Materpark Palu.

Tabel Jumlah Pengunjung Tahun 2015 - 2019. 


\begin{tabular}{|c|c|c|}
\hline No & Tahun & Jumlah pengunjung \\
\hline 1 & 2015 & 106.649 \\
\hline 2 & 2016 & 94.000 \\
\hline 3 & 2017 & 132.428 \\
\hline 4 & 2018 & 16.552 \\
\hline 5 & 2019 & 72.864 \\
\hline
\end{tabular}

Sumber data, Manejer Milenium Waterpark

Berdasarkan tabel 1 di atas menunjukan bahwa jumlah pengunjung setiap tahunnya mengalami kenaikan dan penurunan. Hal-hal yang menyebabkan naik turunnya jumlah pengunjung setiap tahunnya disebabkan karna di Tahun 2015, Promosi yang dilakukan menggunakan semua media sebagai alat promosi, seperti media elektronik dan media cetak sehingga pengunjung 2015 lebih banyak ketimbang pengunjung 2016, karna promosi tahun 2016 hanya menggunakan brosur, sedangkan di Tahun 2017 kembali melakukan promosi dengan menggunakan media cetak dan elektronik. Selain itu juga banyak melakukan iven-iven yang dapat menarik pengunjung untuk berkunjung,diantara iven yang dilakukan ialah mengadakan pertunjukan musik, baik itu musik tradisional maupun modern setiap hari libur. Sedangkan ditahun 2018 mengalami penurunan pengunjung di karenakan, ditahun ini terjadi musibah yang melanda Kota Palu sehingga berkurangnya pengunjung

Dengan daya tarik yang dimiliki oleh permandian Milenium Waterpark, maka perlu di jaga dan merawat fasilitas - fasilitas yang ada dan sering melakukan promosi guna untuk meningkatkan jumlah pengunjung. Mengingat pentingnya keputusan masyarakat berkunjung terhadap promosi, fasilitas, dan lokasi. Maka perlu dilakukan penilitian ilmiah dengan judul ',Pengaruh Promosi, Fasilitas dan Lokasi Dalam Meningkatkan Keputusan Berkunjung Pada Permandian Milenium Waterpark Palu".

\section{Rumusan Masalah}

Berdasarkan latar belakang di atas, maka permasalahan dalam penelitian ini adalah:

1. Apakah Promosi, Fasilitas dan Lokasi berpengaruh serempak Dalam Meningkatkan Keputusan Berkunjung Pada Permandian Milenium Waterpark Palu?

2. Apakah Promosi berpengaruh signifikan Dalam Meningkatkan Keputusan Berkunjung Pada Permandian Milenium Waterpark Palu?

3. Apakah Fasilitas berpengaruh signifikan Dalam Meningkatkan Keputusan Berkunjung Pada Permandian Milenium Waterpark Palu?
4. Apakah Lokasi berpengaruh signifikan Dalam Meningkatkan Keputusan Berkunjung Pada Permandian Milenium Waterpark Palu?

\section{KAJIAN PUSTAKA}

Manajemen Sumber Daya Manusia

Manajemen sumber daya manusia (MSDM) merupakan bagian dari manajemen keorganisasian yang memfokuskan diri pada unsur sumber daya manusia serta pencapaian tujuan organisasi. Tugas MSDM adalah untuk mengelola unsur manusia secara baik agar diperoleh tenaga kerja yang puas akan pekerjaannya. Menurut Umar (2004; 3), MSDM merupakan bagian dari manajemen keorganisasian yang mengfokuskan diri pada unsur sumber daya manusia. Adalah tugas MSDM untuk mengelola unsur manusia secara baik agar diperoleh tenaga kerja yang puas akan pekerjaannya.

Menurut Gomes (2001; 2), manajemen sumber daya manusia adalah pengelolaan sumber daya manusia secara keseluruhan yang tersedia dalam suatu organisasi, baik swasta maupun publik. SDM merupakan satu-satunya sumber daya yang memiliki akal, perasaan, keinginan, kemampuan, ketrampilan, pengetahuan, dorongan, daya dan karya. Semua potensi SDM tersebut sangat berpengaruh terhadap upaya organisasi dalam pencapaian tujuan. Selanjutnya menurut Hasibuan (2011; 10), manajemen sumber daya manusia adalah ilmu dan seni mengatur hubungan dan peranan tenaga kerja agar efektif dan efisien membantu terwujudnya tujuan perusahaan, karyawan dan masyarakat.

Manajemen sumber daya manusia yang efektif berhubungan dengan bentuk dan karakter sebuah organisasi, dimana aktivitas utamanya adalah mendapatkan, mengelola, dan pemutusan sumber daya. MSDM dapat meningkatkan efektivitas manajemen sumber daya manusia dengan menggunakan pendekatan empat langkah yaitu; diagnosis permasalahan, evaluasi praktik yang berjalan, desain sistem manajemen sumber daya manusia dan implementasi sistem (Simamora, 2003; 32).

Gomes (2001; 3) mengemukakan bahwa tugas MSDM berkisar pada upaya mengelola unsur manusia dengan segala potensi yang dimilikinya seefektif mungkin sehingga dapat diperoleh sumber daya manusia yang puas (satisfied) dan memuaskan (satisfactory) bagi organisasi. Perhatian penting MSDM mencakup fungsi manajerial, fungsi operasional dan peran 
serta kedudukan SDM dalam pencapaian tujuan organisasi secara terpadu.

\section{Promosi}

Menurut (Marjun, 2019) Setiap perusahaan harus mampu memberikan pelayanan yang terbaik kepada konsumen, hingga akhirnya tercipta kepuasan dari adanya Dimensi Kualitas Layanan tersebut. Suatu perusahaan tidak hanya menghasilkan suatu produk atau jasa tetapi lebih dari itu bagaimana produk yang telah dihasilkan tersebut diketahui oleh masyarakat. Promosi adalah semua kegiatan yang dilakukan untuk meningkatkan penjualan. Secara lebih mendasar dapat dikatakan bahwa dalam melakukan aktifitas promosi, terjadi suatu komunikasi antara penjual dan pembeli.

Dengan demikian, ada beberapa pengertian dari promosi yang di gunakan, diantaranya :

Menurut Cravens (2003 : 77) promosi adalah perencanaan dan pengendalian komunikasi dari suatu organisasi kepada para konsumen dan sasaran lainnya.

Pengertian promosi juga dikemukakan oleh Kotler (2006 : 17) adalah sebagagai berikut "Promosi meliputi semua alat - alat dalam kombinasi pemasaran yang peranan utamanya adalah untuk mengadakan komunikasi yang sifatnya membujuk, promosi juga merupakan suatu proses komunikasi dari penyampaian amanat atau berita tentang barang atau jasa dari penjualan kepada para konsumen'.

Pengertian di atas menyatakan bahwa kegiatan promosi dimaksudkan untuk mengarahkan konsumen kepada pengambilan keputusan untuk mengkonsumsi barang atau jasa. Hubungan tersebut diatas jelaslah bahwa produsen dalam melaksanakan program promosi berupa informasi untuk merangsang minat atau daya beli konsumen untuk menggunakan produk atau jasa yang ditawarkan dipasaran. Kegiatan promosi dilakukan untuk memberitahukan pasar yang dituju tentang penawaran perusahaan. Promosi yang bersifat informasi penting bagi konsumen karena dapat membantu dalam pengambilan keputusan dalam membeli barang atau jasa.

\section{Fasilitas}

Fasilitas adalah sumber daya fisik yang ada sebelum suatu jasa dapat ditawarkan kepada konsumen. Fasilitas merupakan segala sesuatu yang memudahkan konsumen untuk memenuhi berbagai kebutuhan berkenaan dengan penawaran jasa tersebut. Dalam usaha yang bergerak di bidang jasa, maka segala fasilitas yang ada yaitu kondisi fasilitas, desains, dan kebersihan fasilitas harus diperatikan terutama yang berkaitan erat dengan konsumen (Tjiptono 2001 : 35). Dari penjelasan di atas maka dapat di simpulkan bahwa fasilitas berpengaruh terhadap minat pengujung.

Lokasi

Beberapa pertimbangan yang dilakukan oleh perusahaan dalam mengambil keputusan terkait dengan lokasi perusahaan yaitu:

1. Merupakan pertimbangan yang dipilih konsumen.

2. Merupakan strategi yang penting untuk dikembangkan menjadi persaingan yang sehat.

Lokasi dimulai dengan memilih suatu komunitas. Keputusan ini sangatlah bergantung pada potensi pertumbuhan ekonomis dan stabilitas, persaingan, iklin politik dan sebagainya. Setelah mendapatkan kawasan atau komunitas para pesaing harus memiliki sebuah lokasi yang spesifik. perusahaan harus mempertimbangkan di mana pesaing-pesaingnya berada. Hal-Hal seperti kemungkinan terlihat, tempat parkir, jalan masuk dan keluar, kemudahan akses, serta keselamatan dan keamanan dari lokasi merupakan faktor lain yang memberikan kontribusi pada keberhasilan pemilihan lokasi.

\section{Keputusan Berkunjung}

Dalam mengenal konsumen perlu mempelajari perilaku konsumen sebagai perwujudan dari seluruh aktivitas jiwa manusia dalam kehidupan sehari-hari. Persepsi-persepsi pengaruh orang lain dan motif-motif internal akan berinteraksi untuk menentukan keputusan terakhir yang dianggap paling sesuai. Perilaku konsumen adalah tindakan-tindakan yang dilakukan individu, kelompok atau organisasi yang berhubungan dengan proses pengambilan keputusan dalam mendapatkan, menggunakan barang-barang atau jasa ekonomis yang dapat dipengaruhi oleh lingkungan (Swastha, 2003; 34). Ada 2 aspek penting dari arti perilaku konsumen.

1. Proses pengambilan keputusan.

2. Kegiatan fisik yang kesemuanya ini melibatkan individu dalam menilai mendapatkan dan mempergunakan barangbarang dan jasa ekonomis.

Mempelajari perilaku konsumen akan memberikan petunjuk bagi pengembangan produk baru, keistimewaan produk, harga, saluran pemasaran, pesan iklan dan elemen bauran 
pemasaran lainnya. Titik tolak untuk memahami perilaku pembeli adalah rangsangan tanggapan. Rangsangan pemasaran dan lingkungan mulai memasuki kesadaran pembeli. Karakteristik pembeli dan proses pengambilan keputusan menimbulkan keputusan pembelian tertentu. Tugas pemasar adalah memahami apa yang terjadi dalam kesadaran pembeli mulai dari adanya rangsangan dari luar hingga munculnya keputusan pembelian pembeli.

Menurut Kotler (2004; 67) kelima tahap yang dilalui konsumen dalam proses pengambilan keputusan pembelian dapat dirumuskan sebagai berikut:

1. Pengenalan Masalah

Proses pembelian dimulai dengan pengenalan masalah atau kebutuhan. Jika kebutuhan diketahui maka konsumen akan serta memahami kebutuhan yang belum perlu segera dipenuhi atau masalah dapat ditunda pemenuhannya, serta kebutuhan yang sama-sama harus segera dipenuhi. Jadi pada tahap inilah proses pembelian itu mulai dilakukan.

2. Pencarian Informasi

Seorang konsumen yang telah mengetahui kebutuhannya dapat atau tidak dapat mencari informasi lebih lanjut jika dorongan keinginan kuat, jika tidak kuat maka kebutuhan konsumen itu hanya akan menjadi ingatan belaka. Konsumen mungkin melakukan pencarian lebih banyak atau segera aktif mencari informasi yang mendasari kebutuhan.

3. Penilaian Alternatif

Setelah melakukan pencarian informasi sebanyak mungkin, konsumen menggunakan informasi untuk mengevaluasi beberapa merek alternatif dalam satu susunan pilihan.

4. Keputusan Pembelian

Jika keputusan yang diambil adalah membeli, maka pembeli akan menjumpai serangkaian keputusan yang menyangkut jenis pembelian, waktu pembelian, dan cara pembelian. Pada tahap ini konsumen benar-benar membeli produk.

5. Perilaku Setelah Membeli

Setelah membeli suatu produk, konsumen akan mengalami beberapa tingkatan kepuasan atau ketidakpuasan yang dirasakan, ada kemungkinan bahwa pembeli memiliki ketidakpuasan setelah melakukan pembelian karena tidak sesuai dengan keinginan atau gambaran sebelumnya, dan lain sebagainya.

\section{METODE PENELITIAN Populasi dan Sampel Penelitian}

Populasi dalam penelitian adalah seluruh Populasi adalah wilayah generalisasi yang terdiri dari objek atau subjek yang mempunyai kuantitas dan karakteristik tertentu yang ditetapkan oleh peneliti (Sugiyono, 2010; 117). Adapun populasi dalam penelitian ini adalah para pengguna jasa wisata yang telah melakukan rekreasi pada permandian Milenium Waterpark Palu. jumlah pengunjung Milenium Waterpark pada bulan Juni sampai dengan bulan Agustus 2013 adalah 26.087 orang.

\section{Sampel}

Sampel adalah subset dari populasi, terdiri dari beberapa anggota populasi. Subset ini di ambil karena dalam banyak kasus tidak mungkin kita meneliti seluruh anggota populasi, oleh karena itu kita membentuk sebuah perwakilan yang disebut sampel (Ferdinand, 2006; 47).

Tehnik pengambilan sampel dalam penelitian ini adalah purposive sampling yaitu pengambilan sampel dengan cara memberikan syarat dan kriteria tertentu kepada sampel (Umar, 2004; 19).

Kriteria sampel ditetapkan sebagai berikut:

1) Pengunjung yang sudah lebih dari 2 kali melakukan kunjungan pada Mienium Waterpark Palu.

2) Berusia minimal 17 tahun (mampu memahami setiap item pernyataan).

Jumlah sampel minimal ditentukan dengan rumus Slovin (dalam Ida Manulang 2008: 23):

$$
\begin{array}{ll}
\boldsymbol{n}=\frac{\mathbf{N}}{\mathbf{1 + N}(\boldsymbol{e})^{\mathbf{2}}} & \\
\text { Dimana: } & \text { Jumlah sampel } \\
\mathrm{n} & =\text { Jumlah populasi } \\
\mathrm{N} & =\text { Tingkat kesalahan } \\
\mathrm{e}
\end{array}
$$

Populasi (N) sebanyak 26.087 orang dengan asumsi tingkat kesalahan $(\mathrm{e})=10 \%$ maka jumlah sampel $(\mathrm{n})=$

$$
n=\frac{26.087}{1+26.087(0,10)^{2}}
$$

$n=99,9$ orang $=100$ orang (dibulatkan)

Dengan demikian jumlah sampel dalam penelitian ini sebesar 100 responden.

Uji Asumsi Klasik 
Tujuan uji normalitas adalah untuk mengetahui apakah distribusi sebuah data mengikuti atau mendekati distribusi normal. Uji normalitas bertujuan untuk menguji apakah model regresi berdistribusi normal. Uji normalitas dapat dilakukan dengan analisis grafik dilihat dari titiktitik yang menyebar disekitar garis diagonal yakni distribusi data dengan bentuk lonceng dan distribusi data tersebut tidak menceng ke kiri atau menceng ke kanan. Uji normalitas dilakukan dengan mengunakan pendekatan Kolmogorv Sminorv. Dengan mengunakan tingkat signifikan 5\% (0,05) maka jika nilai Asymp.Sig. (2-tailed) diatas nilai signifikan $5 \%$ artinya variabel Standardized Residual berdistribusi normal.

Normal P-P Plot of Regression Standardized Residual

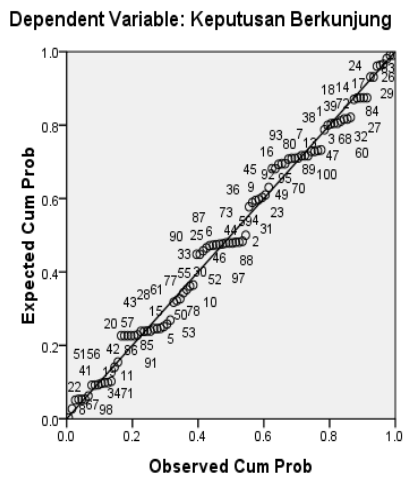

Gambar 1: Pengujian normalitas P-P Plot Sumber: Hasil olahan SPSS 18,0 for windows (Oktober 2019)

\section{Uji Heteroskedastisitas}

Model regresi yang baik adalah yang tidak terjadi Heteroskedastisitas. Untuk menguji Heteroskedastisitas dilakukan dengan analisis grafik. Melaui analisis grafik suatu model regresi diangap tidak terjadi Heteroskedastisitas jika titiktitik menyebar secara acak dan tidak membentuk suatu pola tertentu yang jelas serta tersebar di atas maupun di bawah angka nol pada sumbu Y.

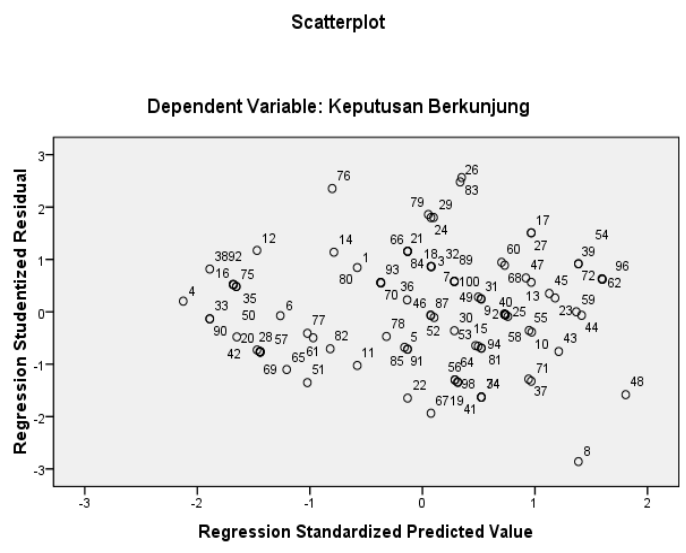

Gambar 2: pengujian Heteroskedastisitas scatterplot.

Sumber: hasil olahan SPSS 18,0 for windows (Oktober 2019)

Gambar 2 memperlihatkan titik-titik menyebar secara acak dan tidak suatu pola tertentu yang jelas serta baik di atas maupun di bawah angka nol pada sumbu Y. Hal ini berarti tidak terjadi Heteroskedastisitas pada model regresi, sehingga model regresi layak dipakai untuk memprediksi keputusan berkunjung berdasarkan masukkan variabel independennya.

Uji Multikolinearitas

Multikolinearitas berarti adanya hubungan linier yang sempurna atau pasti di antara beberapa atau semua variabel yang menjelaskan dari model regresi. Untuk mendeteksi ada atau tidaknya Multikolinearitas dapat diketahui dengan melihat toleransi variabel dan variance inflation factor (VIF) dengan membandingkan sebagai berikut:

a) $\mathrm{VIF}<10$ maka tidak terdapat multikolinearitas

b) Tolerance >0,1 maka tidak terdapat multikolinearitas

Menurut Sugiyono (2009) Gejala Multikolinieritas dapat dilihat dari besarnya nilai tolerance dan VIF (Variance Inflation Factor). Kedua ukuran ini menunjukan setiap variabel independen manakah yang dijelaskan oleh variabel independen lainnya. Tolerance adalah mengukur variabilitas variabel independen yang terpilih yang tidak dijelaskan variabel independen lainnya. Nilai yang dipakai untuk Tolerance $>0,1$ dan VIF <10, maka tidak terjadi Multikolinieritas.

Tabel

Uji Multikolinieritas 


\begin{tabular}{|c|l|c|c|}
\hline \multirow{2}{*}{} & \multirow{2}{*}{} & \multicolumn{2}{c|}{ Statistik } \\
\cline { 3 - 4 } & & Tolerance & VIF \\
\hline 1 & Promosi & .445 & 2.245 \\
\hline 2 & Fasilitas & .328 & 3.047 \\
\hline 3 & Lokasi & .345 & 2.897 \\
\hline
\end{tabular}

Sumber: Hasil olahan SPSS 18 for windows data sudah diolah (Oktober 2019)

\section{Analisis Regresi Linear Berganda}

Analisis regresi linear berganda dalam penelitian ini digunakan untuk mengetahui pengaruh faktor Promosi (X1), Fasilitas (X2) dan Lokasi (X3) terhadap Keputusan Berkunjung Pada Permandian Millennium Waterpark Palu berdasarkan pengujian doperoleh hasil sebagai berikut:

Tabel 2

Hasil Pengujian Regresi Linear Berganda

Faktor Terikat $=$ Keputusan Berkunjung $(\mathrm{Y})$

\begin{tabular}{|l|r|r|r|}
\hline Variabel & $\begin{array}{l}\text { Standardi } \\
\text { zed } \\
\text { Coefficie } \\
\text { nts (Beta) }\end{array}$ & $\begin{array}{l}\text { Std. } \\
\text { Error }\end{array}$ & Sig.t \\
\hline (Constant) & .544 & 1.495 & .717 \\
Promosi & .279 & .099 & .002 \\
Fasilitas & .313 & .116 & .003 \\
Lokasi & .307 & .104 & .003 \\
\hline
\end{tabular}

$\mathrm{n}=100$

Konstanta $=.544$

Koefesien Korelasi $(\mathrm{R})=0,815$

Koefisien Determinasi $\left(\mathrm{R}^{2}\right)=0,664$

F-Statistik $=63.325$

Sig.F $=0,000$

Sumber: Lampiran

Dari hasil pengujian dengan menggunakan regresi linier berganda di atas, maka dapat disusun persamaan regresi berganda dari pengaruh promosi, fasilitas dan lokasi terhadap keputusan berkunjung pada permandian millennium waterpark Palu yaitu:

$\mathrm{Y}=0,544+0,279 \mathrm{X} 1+0,313 \mathrm{X} 2+0,307 \mathrm{X} 3+\mathrm{e}$

Hasil pengujian di atas menunjukan, di mana nilai konstanta 0,544 merupakan bilangan tepat yang berarti terjadi pengaruh promosi (X1), fasilitas (X2) dan lokasi (X3) terhadap keputusan berkunjung pada permandian millennium waterpark Palu yaitu 0,544.

Selanjutnya koefisien regresi faktor promosi (X1) sebesar 0,279 memberikan arti bahwa jika terjadi perubahan X1 sebesar satu satuan maka keputusan berkunjung akan terjadi pula perubahan terhadap keputusan berkunjung pada permandian millennium waterpark Palu sebesar 0,279 dan dengan asumsi variabel lain diangap konstan terjadi pengaruh sebesar 0,279 atau $27,9 \%$ terhadap keputusan berkunjung. Koefesien regresi faktor fasilitas (X2) memberikan arti bahwa terjadi pengaruh sebesar 0,313 atau 31,3\% terhadap keputusan berkunjung pada permandian millennium waterpark Palu. Dan koofisien regresi faktor lokasi (X3) memberikan arti bahwa akan terjadi pula perubahan terhadap keputusan berkunjung pada permandian millennium waterpark Palu sebesar 0,307 atau $30,7 \%$.

Multiple atau koefisien korelasi (R) adalah hubungan antara ketiga variabel bebas yaitu promosi, fasilitas dan lokasi terhadap terhadap keputusan berkunjung pada permandian millennium waterpark Palu sebesar 0,815 atau $81,5 \%$ artinya hubungan variabel bebas (independen) terhadap variabel terikat (dependen) adalah Sangat Kuat.

$\mathrm{R}$ Square atau koefisien determinasi $\left(\mathrm{R}^{2}\right)$ adalah melihat pengaruh antara variabel promosi, fasilitas dan lokasi terhadap keputusan berkunjung pada permandian millennium waterpark Palu sebesar $66,4 \%$ artinya pengaruh variabel bebas (independen) terhadap variabel terikat (dependen). Sedangkan sisanya $33,6 \%$ adalah pengaruh variabel lain yang tidak diteliti dalam penelitian ini.

\section{Pembuktian Hipotesis}

a. Pembuktian Hipotesis Pertama

Hipotesis pertama yaitu pengaruh promosi, fasilitas dan lokasi terhadap keputusan berkunjung pada permandian millennium waterpark Palu. Pembuktian hipotesis pertama mengguanakan uji $F_{\text {sig. Nilai signifikansi } 0,000<}$ $\alpha 0,05$. Maka terbukti ketiga variabel bebas yaitu promosi, fasilitas dan lokasi berpengaruh secara serempak terhadap keputusan berkunjung pada permandian millennium waterpark Palu.

b. Pembuktian Hipotesis Kedua

Hipotesis kedua yaitu untuk mengetahui apakah variabel promosi (X1), secara parsial berpengaruh signifikan terhadap keputusan berkunjung pada permandian millennium waterpark Palu.

Dari tabel 2 diatas bahwa besarnya probabilitas signifikansi variabel promosi (X1) adalah $0,002<$ taraf signifikan yang diisyaratkan 
$\alpha 0,05$. Dengan demikian bahwa secara statistik variabel promosi dalam penelitian ini memberikan pengaruh yang signifikan terhadap keputusan berkunjung pada permandian millennium waterpark Palu.

\section{c. Pembuktian Hipotesis Ketiga}

Hipotesis ketiga yaitu untuk mengetahui apakah variabel fasilitas (X2), secara parsial berpengaruh signifikan terhadap keputusan berkunjung pada permandian millennium waterpark Palu.

Dari tabel 2 diatas bahwa besarnya probabilitas signifikansi variabel fasilitas (X2) adalah $0,003<$ taraf signifikan yang diisyaratkan $\alpha$ 0,05. Dengan demikian bahwa secara statistik variabel fasilitas dalam penelitian ini memberikan pengaruh yang signifikan terhadap keputusan berkunjung pada permandian millennium waterpark Palu.

\section{d. Pembuktian Hipotesis Keempat}

Hipotesis ketiga yaitu untuk mengetahui apakah variabel lokasi (X3), secara parsial berpengaruh signifikan terhadap keputusan berkunjung pada permandian millennium waterpark Palu.

Dari tabel 2 diatas bahwa besarnya probabilitas signifikansi variabel lokasi (X3) adalah $0,003<$ taraf signifikan yang diisyaratkan $\alpha 0,05$. Dengan demikian bahwa secara statistik variabel lokasi dalam penelitian ini memberikan pengaruh yang signifikan terhadap keputusan berkunjung pada permandian millennium waterpark Palu.

\section{Pembahasan}

Hasil pembuktian hipotesis dalam penelitian ini pengaruh promosi, fasilitas dan lokasi terhadap keputusan berkunjung pada permandian millennium waterpark Palu memberikan pembuktian bahwa ketiga variabel independen yaitu promosi, fasilitas dan lokasi memilki pengaruh secara signifikan terhadap keputusan berkunjung pada permandian millennium waterpark Palu. Dengan demikian dinyatakan bahwa hipotesis mengenai pengaruh promosi, fasilitas dan lokasi terhadap keputusan berkunjung pada permandian millennium waterpark Palu dapat diterima.

a. Pengaruh Promosi, Fasilitas dan Lokasi Terhadap Keputusan Berkunjung Pada Permandian Millennium Waterpark Palu

Hasil penelitian membuktikan bahwa penelitian ini seluruh faktor independen berpengaruh positif terhadap keputusan berkunjung pada permandian millennium waterpark Palu. Artinya jika ketiga variabel tersebut diperlukan dalam waktu bersamaan, maka hal tersebut menimbulkan peningkatan keputusan berkunjung konsumen pada permandian millennium waterpark Palu.

b. Hubungan Promosi Dan Keputusan Berkunjung Pada Permandian Millennium Waterpark Palu.

Promosi adalah semua kegiatan yang dilakukan untuk meningkatkan penjualan. Secara lebih mendasar dapat dikatakan bahwa dalam melakukan aktifitas promosi, terjadi suatu komunikasi antara penjual dan pembeli. Dalam mengadakan komunikasi dengan pasar sasaran, promosi sering juga disebut sebagai proses berlanjut karena dapat menimbulkan rangkaian kegiatan selanjutnya dari perusahaan. Oleh karena itu promosi dipandang sebagai arus informasi atau arah yang untuk mengarahkan seseorang atau organisasi kepada tindakan yang menciptakn pertukaran dalam perusahaan. Disamping itu, kegiatan promosi sebagai sarana komunikasi antar produsen dengan konsumen yang dilaksanakan untuk memperkenalkan produk baik jenis, warna, bentuk, struktur harga maupun kualitas produk yang ditawarkan oleh perusahaan. Pimpinan Permandian Millennium Waterpark Palu harus melakukan promosi secara baik kepada konsumen untuk bisa menjadikan permandian tersebut sebagai pilihan konsumen dalam melakukan rekreasi bersama keluarga sehingga harapan konsumen untuk melakukan keputusan bekunjung pada permandian tersebut sesuai dengan keingginan konsumen dan akan terciptanya kepuasan konsumen.

\section{c. Hubungan Fasilitas Dan Keputusan Berkunjung Pada Permandian Millennium Waterpark Palu}

Fasilitas adalah sumber daya fisik yang ada sebelum suatu jasa dapat ditawarkan kepada konsumen. Fasilitas merupakan segala sesuatu yang memudahkan konsumen untuk memenuhi berbagai kebutuhan berkenaan dengan penawaran jasa tersebut. Dalam usaha yang bergerak di bidang jasa, maka segala fasilitas yang ada yaitu kondisi fasilitas, desains, dan kebersihan fasilitas harus diperatikan terutama yang berkaitan erat dengan konsumen. Dari penjelasan di atas maka dapat di simpulkan bahwa fasilitas berpengaruh terhadap keputusan berkunjung pada Permandian Millennium Waterpark Palu. 


\section{d. Hubungan Lokasi Dan Keputusan Berkunjung Pada Permandian Millennium Waterpark Palu \\ Memilih jenis lokasi yang khusus} melibatkan evaluasi serangkaian penjualan. Pada umumnya penjualan ini melihat biaya lokasi versus nilainya bagi pelanggan. Lokasi suatu perusahaan atau tempat permandian akan memiliki pengaruh yang sangat besar terhadap keputusan berkunjung konsumen karena lebih menguntungkan konsumen dan efisiensi waktu tempu konsumen sehingga setiap perusahaan atau jasa hiburan dan rekreasi harus memperhatikan lokasinya agar konsumen lebih berminat untuk berkunjung pada tempat hiburan kita tersebut.

\section{KESIMPULAN DAN SARAN Kesimpulan}

Berdasarkan hasil analisis yang telah dilakukan maka dapat disimpulkan bahwa:

a. Promosi memiliki pengaruh terhadap keputusan berkunjung konsumen pada permandian millennium waterpark Palu.

b. Fasilitas memiliki pengaruh terhadap keputusan berkunjung konsumen pada permandian millennium waterpark Palu.

c. Lokasi memiliki pengaruh terhadap keputusan berkunjung konsumen pada permandian millennium waterpark Palu.

\section{Saran-Saran}

Berdasarkan kesimpulan yang di ambil, maka penulis memberikan saran sebagai berikut:

a. Hendaknya pimpinan permandian millennium waterpark harus memperhatikan promosi dan fasilitas agar konsumen merasa puas untuk berkunjung pada tempat permandian tersebut.

b. Pimpinan harus meningkatkan kualitas sumber daya manusia atau para pegawainya agar mampu memberikan pelayanan yang terbaik bagi konsumen yang berkunjung pada permandian tersebut.

\section{DAFTAR PUSTAKA}

Assael, 2012. Consumer Beaviouv And Marketing Action. Fourth Edition, Kent Publising. New York..

Basu Swasta, (2007). "Perilaku Konsumen Konsep Dan Penerapannya” ,Penerbit: Erlangga. Jakarata.

Cravens, David, W. 2003. Pemasaran Strateg. Edisi Ke 4. Jilid 2, Erlangga, Jakarta
Ehrenberg. 1974. Riset Pemasaran. Jakarta: Pt Gramedia Pustaka Utama.

Ferdinand. 2006, Metode Penelitian Manajemen, Semarang: Bp

Ferdinand. 2002. Strctural Equition Mode Ling Dalam Penilitian Manajement. Badan Penerbit, Universitas Di Ponegoro Semafrang.

Husein, U. 2004, Metode Penelitian Untuk Skripsi Dan Tesis Bisnis, Cet Ke 6, Jakarta: Pt Raja Grafindo Persada.

Husein, U. 2008. Metode Riset Bisnis. Bandung: Alfabeta.

Husein, U. 2001. Metode Penilitian Kuntitatif. Jakarta Pt Bumi Aksara.

Joseph, 2002. Manajemen Pemasaram Jasa , Jakarta : Alemba Empatkotler, P. 2004. Marketing Manajemen Pemasaran. Edisi Ke Dua. Jakarta : Pt Index

Kotler, P. And Nurfana. 2012. Prinsip - Prinsip Pemasaran. Edisi 13, Jilid Satu. Jakarta: Erlangga.

Kotler, P. 2006. Manajemen Pemasaran. Edisi 11. Jilid 1. Pt Indekx Jakarta.

Kopalle, K. Preven And Dobald, L. 1995. Starege Pemasaran. Jakarta.Pt Alex Media.Ss

Kuncoro, Madrajat. 2004. Metode Riset Untuk Bisnis Dan Ekonomi.Jakarta : $\mathrm{Pt}$ Gramedia Pustaka.

Latoki, L. (2019). Pengaruh Kepuasan Konsumen Terhadap Loyalitas Merek Kartu Prabayar Im3 Pada Pegawai Kantor Gubernur Sulawesi Tengah. Jurnal Ekonomi Trend, 7(1), 1-11. Https://Doi.Org/10.31970/Trend.V7i1.169

Marjun, M. (2019). Pengaruh Di Mensi Dimensi Kualitas Layanan Terhadap Kepuasan Pasien Rawat Inap Bpjs Kesehatan Center Rumah Sakit Umum Daerah Anutapura. Jurnal Ekonomi Trend, 7(1), 12-26. Https://Doi.Org/10.31970/Trend.V7i1.170

Santoso, S. 2001. Mengolah Data Statistik Secara Profesional. Jakarta: Pt. Alex Media Komputindo.

Sugiyono. (2010). Metodepenelitian Kuantitatif Kualitatif \& Rnd. Bandung : Alfabeta Undip

Simamora. 2004.Prosedur Penilitian, Suatu Pendekatan Praktek. Jakarta : Rineka Cipta.

Sahifman, And Kanuk. 2000. Consumer Bahavior. Sevent Edition. Prentice-Hal, Inc. 
Sciffman, Leon Dan Kanuk, ;Leslie Lazar, 2008. Consumer Bahavior. Sevent Edition. Prentice Hall.

Setiadi, Nugroho J. 2003.Keputusan Konsumen. Prenada Media. Jakarta.

Tjiptono, F. 2005. Strategi Pemasaran. Edisi 2. Penerbit Andi. Ofset. Yogyakarta.

Tjiptono, F, 2001, Manajemen Jasa. Andi Offset, Yogyakarta.

Tjiptono, F. 2006, Manajemen Pemasaran Jasa, Yogyakarta Tjiptono, F. 2005, Pemasaran Jasa, Edisi 1, Malang: Bayumedia Publishing.

William J. And Stanton 2013. Center Of Academic Publishing Service. Dalam . Sunyoto. "Service Are Indentifiable, Intengible Aktifities That Are The Main Object of A Transaction Disignet To Provide Want Satisaffaction To Consumer". (Hal. 1 Sampai 7) Yogyakarta.

Zeithaml, A. Valarie And Mary Jo Bitner. 2011. Service Marketing. Singapore: Mcgraw Hill, 